\title{
Enigmatic linear furrows and pits on the upper continental slope, northwest Labrador Sea: are they sediment furrows or feeding traces?
}

\author{
Heiner Josenhans \\ Atlantic Geoscience Centre, Geological Survey of Canada, Bedford Institute of Oceanography \\ P.0. Box 1006, Dartmouth, Nova Scotia B2Y 4A2 \\ and \\ Chris Woodworth-Lynas \\ Centre for Cold Ocean Resources Engineering, Memorial University of Newfoundland \\ St. John's, Newfoundland AlB $3 X 5$ \\ Date Received March 13, 1988 \\ Date Accepted June 28, 1988
}

\begin{abstract}
Linear furrows and pits were observed from a submersible on the continental slope east of Hudson Strait in water depth ranging from 1004 to $715 \mathrm{~m}$ (Fig. 1). The parallel to sub-parallel furrows are typically $15-40 \mathrm{~cm}$ wide and $20-60 \mathrm{~cm}$ deep. These enigmatic features resemble deep-water, current-formed sedimentary furrows but differ in two significant aspects: (1) they consistently have blocky rims (berms) that appear to have been formed by the ploughing action of a rigid object, and (2) they lack any evidence of formation by bottom currents. We describe the local geological setting and compare the furrows with conventional sedimentary furrows. Our observations lead us to propose three tentative mechanisms for furrow formation: (1) formation by dragging of fins or mandibles of deep diving animals such as whales as they forage on the seafloor, (2) current driven ice which is negatively bouyant because of entrapped glacial sediment, or (3) furrowing by current-driven sponge balls which were observed in the troughs of the furrows.
\end{abstract}

Des plongées en submersible sur la pente continentale à l'est du détroit d'Hudson ont révélé des sillons linéaires et des dépressions par une profondeur de 715 à $1004 \mathrm{~m}$. Ces sillons sont parallèles on presque, typiquement d'une largeur de 15 à 40 $\mathrm{cm}$ et d'une profondeur de 20 à $60 \mathrm{~cm}$. Ces structures énigmatiques évoquent les sillons sédimentaires dûs à l'action des courants sur les grands fonds mais en different sur deux points principaux: (1) elles présentent constamment des bordures (replats) morcelées qui semble résulter d'un labourage par un objet rigide et (2) la preuve de leur formation par des courants de fond fait défaut. On décrit le cadre géologique régional et compare ces sillons aux sillons sédimentaires conventionnels. A la lumière de nos observations, trois options s'offrent pour expliquer leur formation: (1) trainage des nageoires ou rostres d'animaux plongeant à de grandes profondeurs, tels les baleines, qui draguent le fond, (2) reclage par des glaces véhiculées par les courants et qui sont plus denses du fait d'un lest de sédiment glaciaire ou (3) affouillement par suite de l'action des courants sur les boules spongiaires qui jalonnent le fond des sillons.

\section{INTRODUCTION}

Below the continental shelf break at $>700 \mathrm{~m}$, Sea MARC I sidescan images show meandering lineations that trend downslope to a depth of $2000 \mathrm{~m}$ (Fig. 2). The lineations may represent proglacial flow channels and levees formed from material brought to the shelf edge and discharged by a large ice sheet grounded at the $700 \mathrm{~m}$ isobath approximately 8,000 years B.P. (Josenhans $e t$ al., 1986). Above $700 \mathrm{~m}$ water depth, on the relatively flat seabed of eastern Hudson Strait, numerous large parallel iceberg scours occur which may have been formed from icebergs that calved from the terminus of the ice margin following retreat of the ice sheet. There are no iceberg scour marks in water deeper than 700 m.

A submersible dive surveyed the area between the $1004 \mathrm{~m}$ and $715 \mathrm{~m}$ isobath within the area of the interpreted proglacial flow channels (Fig. 2). During the dive the down-slope trending MARITIME SEDIMENTS AND ATLANTIC GEOLOGY
[Traduit par le joumal]

channels were not identified. Instead, small-scale sub-parallel linear furrows were observed which are $15-40 \mathrm{~cm}$ wide and 20 $60 \mathrm{~cm}$ deep and are parallel to the regional isobaths. The furrows are characterized by the presence of blocky berms along their flanks. We suspect that the acoustically-defined contour-normal lineations on the Sea MARC I images represent subtle changes in sediment texture and have little, if any, vertical relief. The small scale contour-parallel furrows were not seen on the Sea MARC I records probably because: (a) the sidescan transducers were "looking" along the features and could not detect changes in relief; (b) the Sea MARC I system operates at low frequencies (27-30 kHz, Kosalos and Chayes, 1983) which prevents the resolution of such small scale seabed features; and (c) the features are developed in a thin acoustically transparent veneer of sediment which mantles the down-slope trending pattern observed on the Sea MARK I images. 


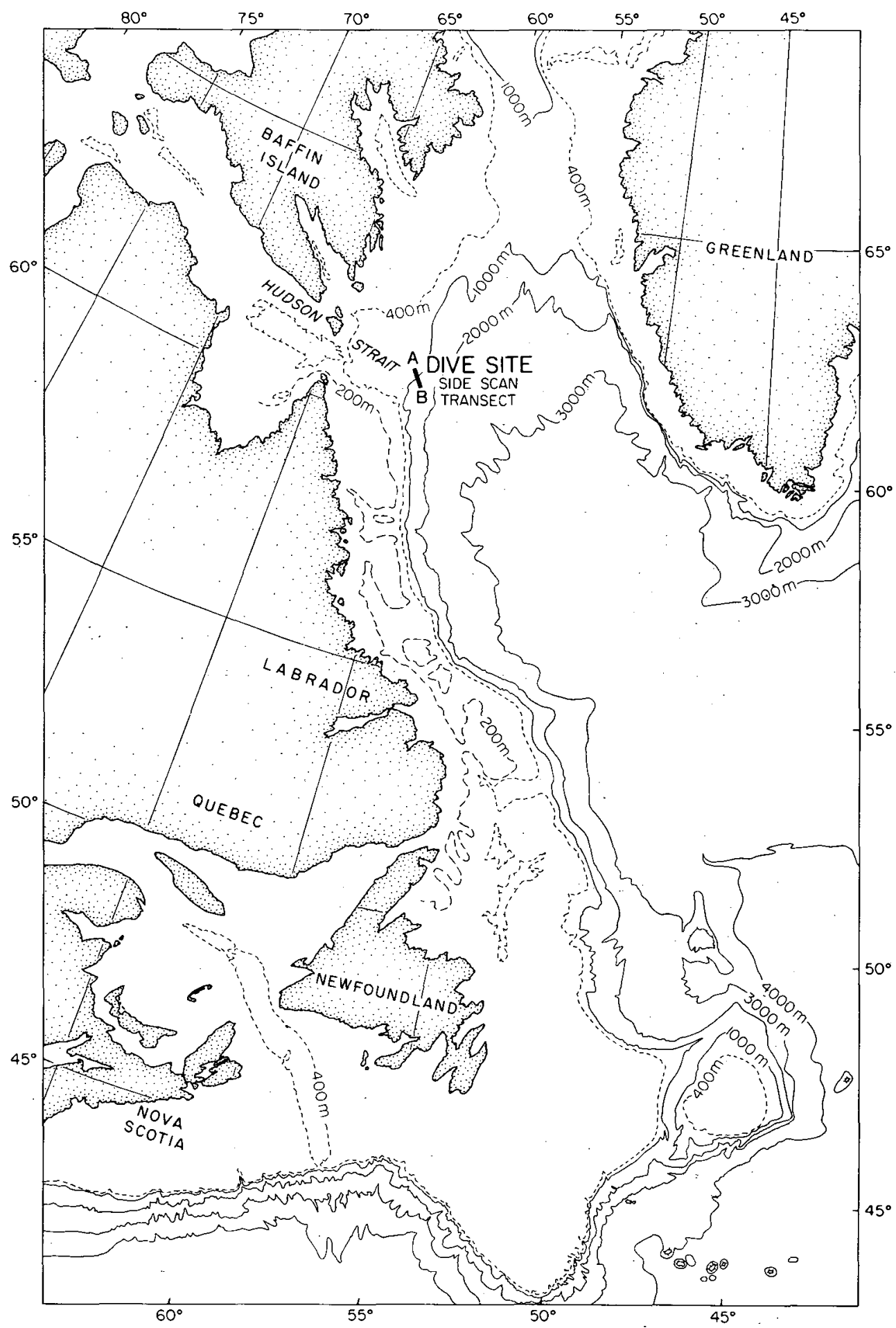

Fig. 1. Index map showing location of Sea MARC I transect, dive site and regional bathymetry.

\section{SEDIMENTARY FURROWS}

Sedimentary furrows in many ways resemble the furrows we describe in this report but differ in numerous important aspects. Sedimentary furrows have been described by Flood $(1981,1983)$ as parallel to sub-parallel longitudinal bedforms which form in fine-grained cohesive sediments in the deep sea, estuaries and large lakes. They range in width between 1 and $150 \mathrm{~m}$ and have depths between 1 and $27 \mathrm{~m}$ (Flood, 1983). They are found in subaqeous areas where directionally stable currents flow at velocities of 5 to $>20 \mathrm{~cm} / \mathrm{sec}$. They are formed by converging helical flow patterns (Dyer, 1970) which erode the linear furrows. Sedimentary furrows have been observed remotely using sidescan sonar imagery, deep towed cameras and visually by means of direct observations from submersibles. They are found on the continental shelf in the English Channel (Belderson et al., 


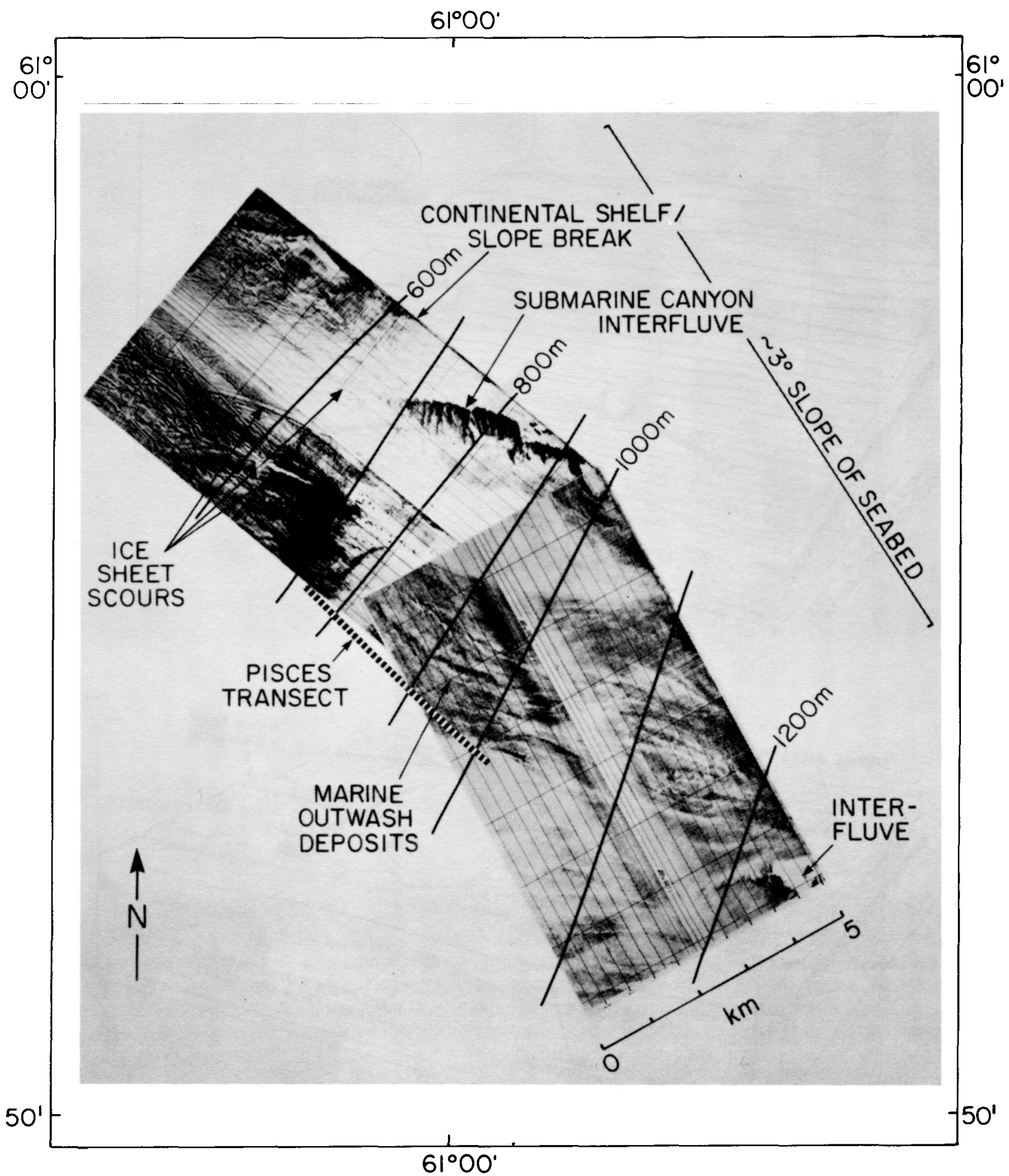

Fig. 2. Interpreted Sea MARC I sidescan sonar profile with superimposed isobaths and location of dive transect. The dive transect is partly off the sidescan coverage due to current offset during descent. Note the marked shelf-slope transition with iceberg scours on the shelf in water depths < 700 $\mathrm{m}$, and down slope trending lineations extending into deeper water. The lineations on the slope are interpreted as proglacial flow channels formed when an ice margin stood at the shelf edge about 8000 years B.P.

1972), and also in the deep Atlantic and Pacific oceans in water depths between 1.5 to $6 \mathrm{~km}$ (Lonsdale and Spiess, 1977; Flood and Hollister, 1980). Similar features have been described on land by Karcz (1967) and appear to have been formed by spring floods which flow rapidly, and in a helical mode. Sedimentary furrows can be asymmetric in cross-section but they are always reported as grooves or furrows without rims or berms along their flanks. We do not think that the features which we have described are sedimentary furrows because of the presence of blocky pushed up berms implying a ploughing mechanism by a solid object, and also because there were no erosional or depositional current generated bedforms associated with the furrows (see Fig. 3). 

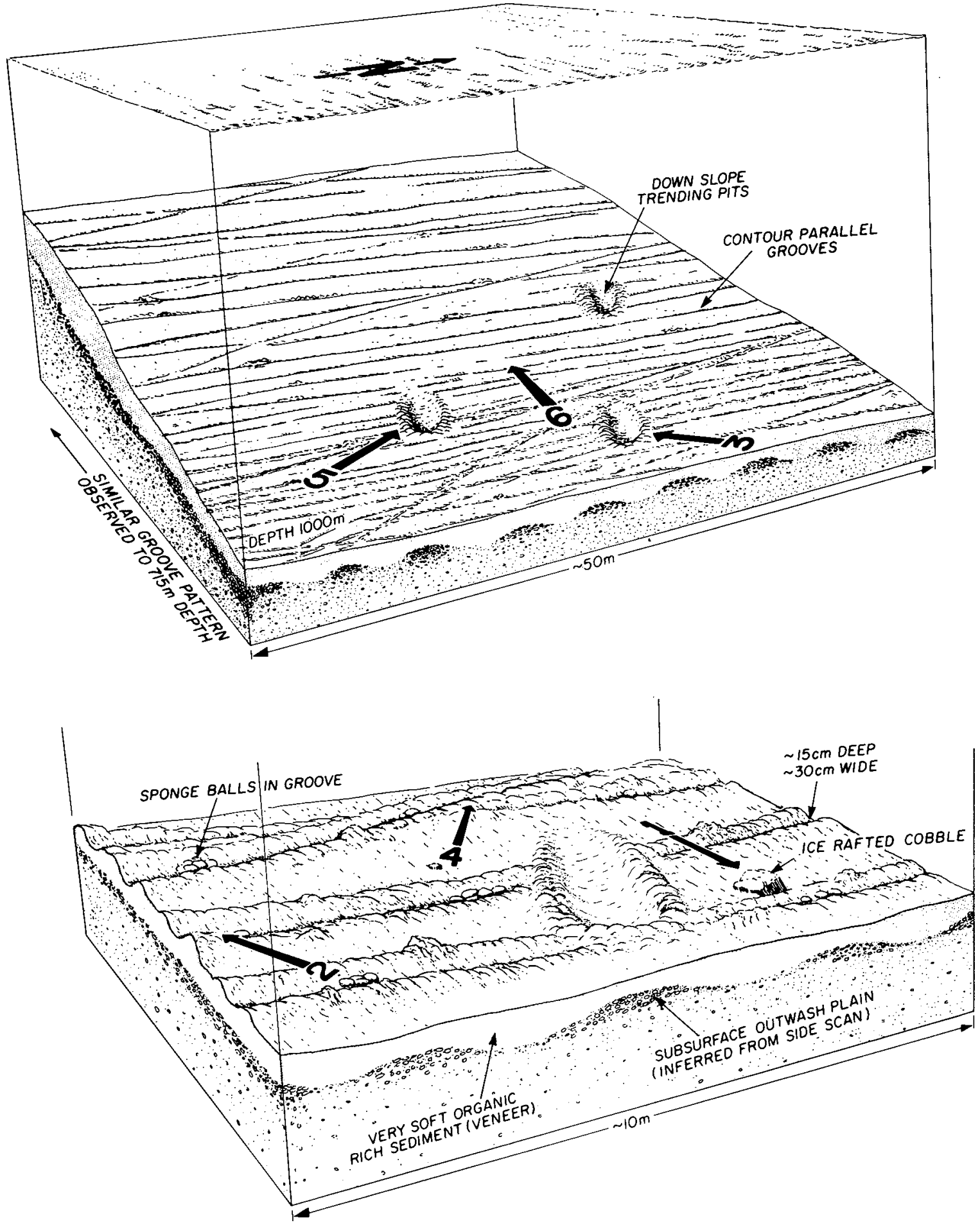

Fig. 3. Block diagram of isobath parallel linear furrows. Note the conspicuous berms and cross-cutting of these sub-parallel features. The arrows indicate the orientation of the bottom photographs shown in Figure 4. The lower block diagram is an enlarged view and shows the pit illustrated by Figure 4, No. 3.

\section{BOTTOM CURRENTS}

The Labrador shelf edge and slope are dominated by the southward-flowing Labrador Current. The Baffin Island Current from the north combines with water from Hudson Strait and flows south to form part of the Labrador Current (Allen and Huntley, 1977). The north-flowing West Greenland Current divides south of the Davis Strait Ridge, part flowing into Baffin Bay and part flowing west to join the outer Labrador Current off Hudson Strait. We noted variations in the strength and direction of the bottom currents during the four hour dive. Current velocities of approximately $1.4 \mathrm{kmh}^{-1}$ towards the southeast were noted at the beginning of the dive and currents of similar speed but flowing southwest parallel to contours were noted during the 
last hour between the $870 \mathrm{~m}$ and $715 \mathrm{~m}$ isobath. No hydrodynamic sedimentary bedforms or current scour features were observed during the dive. The bottom water temperature was $3.1^{\circ} \mathrm{C}$ compared to $0^{\circ}$ at the sea surface. The marked temperature stratification suggests that the currents observed at the seafloor were part of the warm Labrador sea waters which flow contour parallel at velocities up to $20 \mathrm{~cm} \mathrm{~s}-1$ (Carter and Schafer, 1983).

\section{VISUAL OBSERVATIONS FROM SUBMERSIBLE}

The dive transect traversed approximately $5 \mathrm{~km}$ upslope. Visibility was excellent and extended the range of floodlight illumination, a distance of $10-15 \mathrm{~m}$. The following description of seabed features was observed throughout the transect. At a depth of $1004 \mathrm{~m}$, the seabed consisted of light grey poorly consolidated muddy, gravely sand. A push core was taken at the beginning of the dive with the manipulator arm and full retrieval of the $20 \mathrm{~cm}$ core was obtained. Subsequent analysis of the core shows that the sediment is an almost "soupy", weakly stratified mix of small pebbles and broken shell debris supported in a mud matrix rich in sponge spicules (Table 1).

The (upslope) submersible traverse was consistently normal to small-contour parallel furrows. The furrows are generally rectangular in cross-section and variable in size but typically have depths of $20-60 \mathrm{~cm}$ and widths of $15-30 \mathrm{~cm}$ (Fig. 3). The edges of the furrows have small ridges or berms of blocky disturbed material that appears to have been displaced from the furrow troughs. However, the combined volume of the ridges appears to be less than the volume of missing material in the furrow. One of the furrows was followed for $200 \mathrm{~m}$. It was observed to be contour-parallel, and uniform in shape with a depth of $40 \mathrm{~cm}$ and width of approximately $30 \mathrm{~cm}$. Similar subparallel furrows in various states of preservation dominate the seafloor along the submersible transect.

Associated with these contour-parallel furrows are occasional oval-shaped pits. These pits consistently cross-cut the furrows obliquely at angles of approximately $45^{\circ}$ (Fig. 3). The pits are 2-3 m long, up to $1.5 \mathrm{~m}$ wide, and $1.5 \mathrm{~m}$ deep and often steep-sided. Their margins are generally characterized by raised rims of disturbed material, the volume of which, like the furrows, does not match the total volume of the depression. Isolated (granitic) boulders were occasionally seen partially buried in the seabed (Fig. 4). The boulders are assumed to be ice rafted and do not appear to be associated with formation of the oval pits. The partial burial of the boulders illustrates the weak bearing capacity of the substrate. Near the end of the dive some of the furrows and pits were seen to be occupied by dense, spherical yellow sponges balls up to $30 \mathrm{~cm}$ in diameter. Most sponges were covered by a fine layer of silt. One cobble sized sponge ball was taken to the surface and found to be dense and rigid with an estimated specific gravity of 1.5 .

\section{SPECULATIONS ON THE ORIGINS AND AGE OF THE FURROWS AND OVAL PITS}

The difference in orientation, morphology and relative age of the furrows and the oval pits suggests a separate mechanism for
Table 1. Textural Analysis from $20 \mathrm{~cm}$ Core (in \%).

\begin{tabular}{lc} 
Core Top & Core Bottom \\
\hline Gravel $=1.2$ & 5.5 \\
Sand $=26.9$ & 56.8 \\
Silt $=33.6$ & 20.4 \\
Clay $=38.1$ & 16.9 \\
\hline
\end{tabular}

each. The sub-parallel nature of the furrows suggests formation by means of a raking process. Furrowing by the action of bottom trawl fishing apparatus is considered unlikely because of the extreme water depth and limited fishing activity in the area. The uniformity and areal extent of the furrows implies a large scale process. Mass wasting (i.e., slump scarps) is ruled out because the presence of berms implies mechanical action at the surface rather than subsurface faulting or creep. Scouring by icebergs is ruled out because the maximum depth of iceberg scours seen on the Sea MARC I image (Fig. 2) is $700 \mathrm{~m}$, which is shallower than the study area. Currents as the primary mechanism are also ruled out because we saw no evidence of erosive or depositional sedimentary features.

Pits similar to those described here, have been attributed to whale foraging by Nelson and Johnson (1987) and by Hein and Syvitski (1987). According to P.F. Brodie (personal communication, 1987) the study area is known for its high abundance of Bottle Nose whales. Such whales can remain submerged for over 90 minutes and reach depths in excess of $1000 \mathrm{~m}$ ! Other deep diving animals such as beluga, narwhal and sperm whales, as well as hooded and bearded seals, are also known to occur in this area. We speculate that the pits are formed by deep diving animals impacting or foraging on the (organic rich) seabed in a manner similar to that described by Nelson and Johnson (1987).

The linear furrows are more enigmatic. We suggest that the mechanism forming the furrows involves an implement which is pushed horizontally through the sediment (veneer) perhaps by local contour parallel currents. Although the precise mechanism is unknown we suggest three contrasting mechanisms: (1) the implements may be the fins (or jaws) of deep diving animals which are dragged along the seabed by contour parallel currents in their search for food. Altematively, (2) the implements may be protuberances on current-borne masses of ice that are negatively bouyant because of entrapped englacial sediment, or (3) the soupy sediment is plowed by current driven sponge balls such as those observed in the furrow troughs.

\section{SUMMARY}

Sea MARC I images of the continental slope in the northwest Labrador Sea have shown down-slope trending acoustic pattems 
1

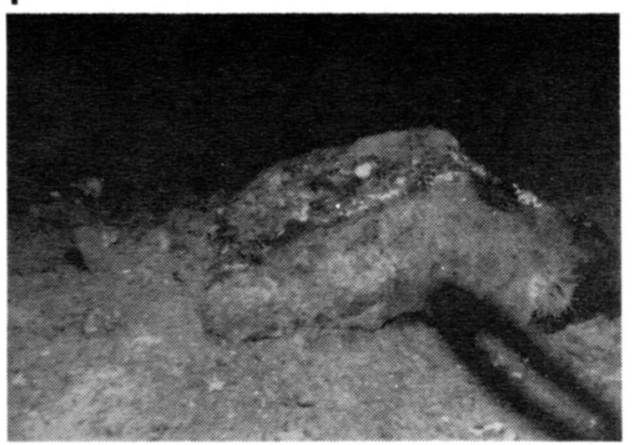

3

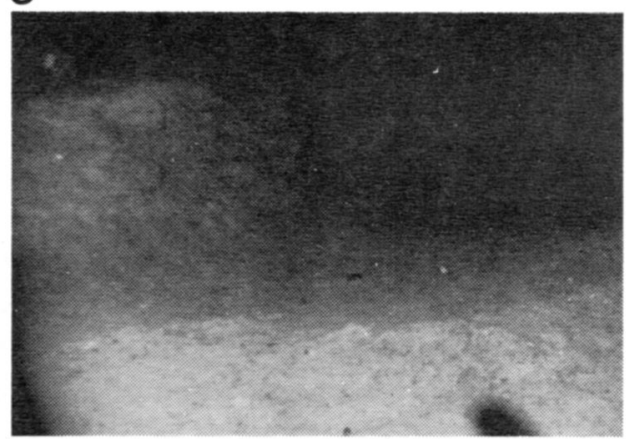

5

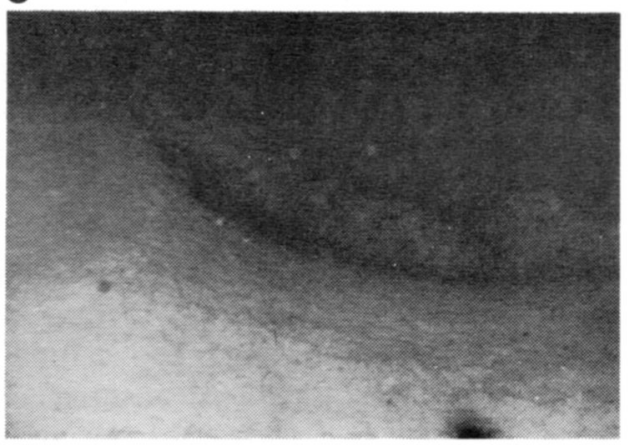

2

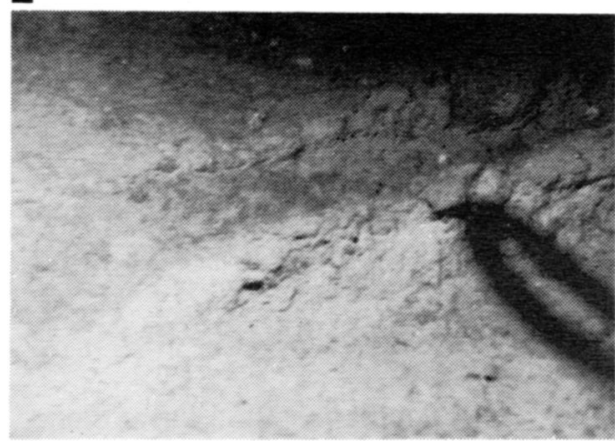

4

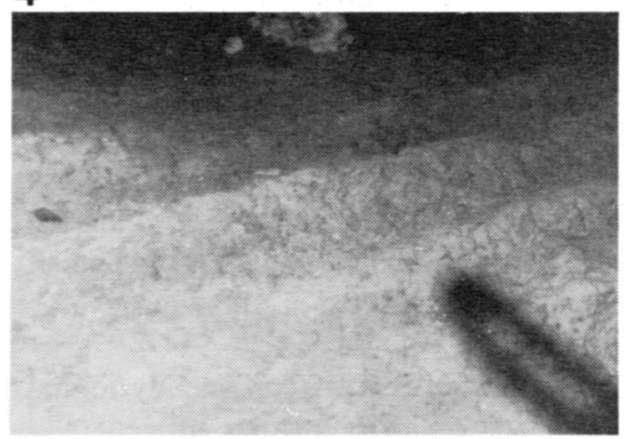

6

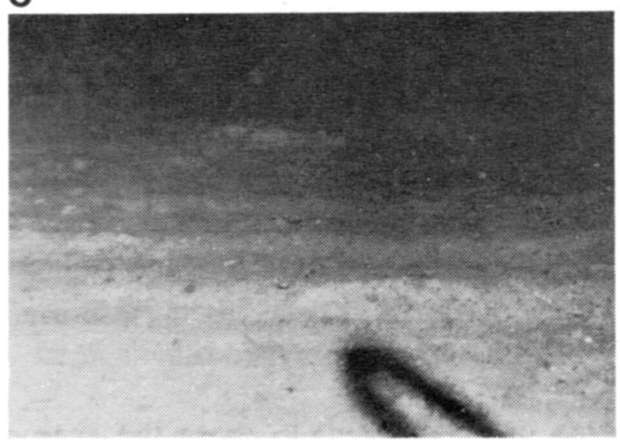

Fig. 4. Bottom photographs showing the detailed aspects of the furrowed terrain as seen from the submersible. The orientation of the photos is shown by the arrows in Figure 3. The oval shadow is caused by a hydraulic hose in front of the viewport. Field of view is approximately $2 \mathrm{~m}$ in all cases. (1) Partially submerged ice rafted boulder resting in the furrowed seafloor indicating the soupy nature of the seafloor. (2) Detail of furrow showing raised blocky berm. (3) A shallow oval pit truncating the furrows (seen in foreground). (4) Typical intensely furrowed seafloor. (5) An oval pit about $75 \mathrm{~cm}$ deep possibly formed by for aging whales. (6) Low angle oblique view of furrows indicating complete dominance of the seafloor by this process.

between a depth of 700 to $2500 \mathrm{~m}$ which are interpreted to represent low amplitude proglacial flow channels formed at the margin of a former ice shelf approximately 8000 years B.P. Our visual observations failed to detect these features, and instead identified a thin veneer of mostly organic, loosely consolidated, cohesive sediments. Cut into these sediments are laterally continuous, isobath-parallel furrows typically 20 to $30 \mathrm{~cm}$ wide and 15 to $20 \mathrm{~cm}$ deep with raised berms on either side of the furrow. Isolated pits, also with raised berms, were found throughout the area but with their long axes generally oriented downslope at $\mathbf{4 5}$ degrees to the contours. The furrows were found beyond the maximum depth of iceberg scouring, and in some respects, resemble sedimentary furrows described throughout the worlds oceans. However, they differ in two important aspects: (1) they show no evidence of current scouring or control on deposition, and (2) the raised berms strongly suggest formation by ploughing. These unusual furrows cover the entire seafloor over the area of the dive which surveyed a range between 1004 and $715 \mathrm{~m}$ of water depth. The angular surfaces and lack of biogenic colonization on the furrow berms suggests that the features are recently formed. We suggest that the furrows are formed by deep diving animals in contact with the seabed whilst moving along in search of food or by negatively buoyant objects such as large sponge balls (or other biogenic debris), or possibly by debris laden fragments of iceberg ice which are transported by isobath parallel flowing bottom currents. We suggest the pits are formed by deep diving whales or seals impacting the seabed. 


\section{ACKNOWLEDGEMENTS}

We thank the pilots and support crew of the Department of Fisheries and Oceans submersible, PISCES IV, for their enthusiasm and support and also the officers and crew of the support vessel PANDORA II. We thank our colleagues Vaughn Barrie and particularly A. Grant for stimulating discussions and helpful ideas, and Harvey Slade for drafting the figures. A. Grant, J. Syvitski, D. Piper and B. Pelletier reviewed the manuscript and provided helpful suggestions. Geological Survey of Canada contribution No. 53786.

ALLEN, A.A. and HUNTLEY, D.A. 1977. Currents at the offshore edge of the Labrador current. In Port and ocean engineering under arctic conditions. Edited by D.B. Muggeridge and G.R. Peters. Proceedings, Vol. 2, pp. 927-937.

BELDERSON, R.H., KENYON, N.H., STRIDE, A.H., and STUBBS, A.R. 1972. Sonograms of the seafloor. Elsevier Publishing Company, Amsterdam.

CARTER, L. and SCHAFER C.T. 1983. Interaction of the westem boundary undercurrent with the continental margin off Newfoundland. Sedimentology, 30, pp. 751-768.

DYER, K.R. 1970. Linear erosional furrows in Southampton Water. Nature, 255, pp. 56-58.

FLOOD, R.D. and HOLLISTER, C.D. 1980. Submersible studies of deep-sea furrows and transverse ripples in cohesive sediments. Marine Geology, 36, Ml-M9.

FLOOD, R.D. 1981. Distribution, morphology, and origin of sedimentary furrows in cohesive sediments, Southampton Water. Sedimentology, 28, pp. 511-529.

1983. Classification of sedimentary furrows and a model for furrow initiation and evolution. Geological Society of America Bulletin, 94, pp. 630-639.

HEIN, F.J. and SYVITSKI, J.P.M. 1987. Seafloor pits in deep fjords, Baffin Island: Possible feeding traces. Submitted to Geomarine Letters. In review.

JOSENHANS, H.W.,ZEVENHUIZEN, J., and KLASSEN, R.A. 1986. The Quatemary geology of the Labrador shelf. Canadian Journal of Earth Sciences, 23, pp. 1190-1213.

KARCZ, I. 1967. Harrow marks, current-aligned sedimentary structures. Journal of Geology, 75, pp. 113-121.

KOSALOS, J.G. and CHAYES, D.N. 1983. A portable system for ocean bottom imaging and charting. In OCEANS '83, Proceedings of the third working symposium on oceanographic data systems, pp.1-8.

LONSDALE, P. and SPIESS, F.N. 1977. Abyssal bedforms explored with a deeply towed instrument package. Marine Geology, 23, pp. 57-75.

NELSON, H. and JOHNSON, K.R. 1987. Whales and walruses as tillers of the seafloor. Scientific American, 256, pp. 112-117. 